\title{
PENGGUNAAN MIKROORGANISME DALAM INDUSTRI PEMROSESAN MINERAL
}

\author{
The Use of Microorganism in Mineral Processing Industry
}

\author{
SRI HANDAYANI \\ Puslitbang Teknologi Mineral dan Batubara \\ Jalan Jend. Sudirman 623 Bandung 40211 \\ Telp. (022) 6030483, Fax. (022) 6003373 \\ e-mail: sri.handayani@esdm.go.id
}

\begin{abstract}
ABSTRAK
Kebutuhan akan logam berharga seperti emas, nikel, tembaga, silika, dan logam tanah jarang terus meningkat seiring dengan pertumbuhan penduduk dan perkembangan industri. Sementara itu, industri pertambangan menghadapi beberapa masalah penting seperti biaya penambangan dan pemrosesan yang makin meningkat serta tuntutan yang makin ketat dalam pencegahan pencemaran lingkungan dari penambangan dan pemrosesan mineral. Untuk menjawab permasalahan tersebut, mikroorganisme telah dimanfaatkan dalam industri pemrosesan mineral secara luas di dunia untuk memproduksi logam-logam berharga dari mineral kadar rendah dan kompleks, serta dari ampas dengan biaya lebih ekonomis dan lebih ramah lingkungan. Namun di Indonesia, teknologi menggunakan jasa mikroorganisme itu masih terbatas dalam skala laboratorium dan belum diterapkan dalam skala industri. Tulisan ini membahas beberapa landasan teori dasar pemanfaatan mikroorganisme dalam pemrosesan mineral, aplikasi komersialnya yang telah ada di beberapa negara di dunia, tantangan dan kendalanya serta potensi aplikasinya untuk diterapkan dalam industri pemrosesan mineral di Indonesia. Bioteknologi mineral ini diharapkan dapat berperan pada peningkatan perolehan logam-logam berharga dari bijih marjinal atau dari ampas pemrosesan mineral yang masih mengandung logam-logam berharga kadar rendah namun bernilai tinggi sehingga dapat memberikan nilai tambah terhadap produk industri pemrosesan mineral di Indonesia.
\end{abstract}

Kata kunci: mikroorganisme, pemrosesan mineral, bijih kadar rendah.

\begin{abstract}
The need of precious metals such as gold, nickel, copper, silica, and rare earth metals continues to increase along with population growth and industrial development. Meanwhile, the mining industry faces several important issues such as increased mining and processing costs and increasingly stringent demands on pollution prevention from mining and mineral processing. To solve the problems, microorganism has been used in the mineral processing industry worldwide to produce valuable metals from low grade and complex minerals as well as from tailing at a more economical cost and environmentally friendly. However in Indonesia, this technology of using microorganism is still limited to laboratory scale and has not yet been applied at industrial scale. This paper discuss the theory of using microorganism in mineral processing, its commercial application in several countries worldwide, challenge and obstacle, and its potential to be applied at industrial scale in Indonesia. It is hoped that this mineral biotechnology can contribute to increasing the recovery of valuable metals from marginal ores or mineral processing waste that still contains low grade but high value metals. Therefore, it will provide value added to the products of mineral processing industry in Indonesia.
\end{abstract}

Keywords: microorganisms, mineral processing, low grade ore. 


\section{PENDAHULUAN}

Pesatnya perubahan dan perkembangan teknologi serta terus meningkatnya pertumbuhan penduduk mengakibatkan kebutuhan akan bahan logam semakin besar jumlahnya. Di samping itu, semakin banyak jenis dan variasi logam yang digunakan oleh industri teknologi material dan komponen. Pada saat ini, logam yang berperan penting di industri diperkirakan sudah mencapai 62 dari 94 unsur logam yang secara alami terdapat pada sumberdaya mineral, baik keberadaannya sebagai logam utama maupun logam ikutan.

Indonesia dikaruniai kekayaan mineral yang beraneka ragam dengan cadangan cukup melimpah, dan telah menjadi produsen emas, tembaga, timah dan nikel dunia. Namun di sisi lain, selama 20 tahun terakhir, industri pertambangan menghadapi beberapa masalah penting seperti biaya penambangan dan pemrosesan yang makin tinggi, harga logam yang fluktuatif dan tidak stabil di pasar internasional serta tuntutan yang makin ketat dalam hal pencegahan pencemaran lingkungan dari industri pertambangan dan pemrosesan mineral, khususnya yang berkaitan dengan pencemaran dari pemrosesan mineral sulfida. Kondisi ini lebih diperburuk lagi oleh semakin sulitnya mendapatkan kadar logam berharga yang tinggi dalam bijih, serta semakin sedikitnya cadangan mineral berkadar tinggi (Butu $d k k$., 2016). Situasi ini telah mendorong pesatnya perkembangan teknologi baru di bidang pemrosesan mineral yang bisa diterapkan untuk mengolah mineral berkadar rendah serta relatif lebih aman ditinjau dari aspek lingkungan, yang tidak bisa lagi menggunakan teknologi konvensional (Borja $d k k ., 2016$; BobadillaFazzini dkk., 2017). Dalam hal ini, bioteknologi, khususnya metode bioleaching dan biooksidasi telah menawarkan kesempatan sekaligus tantangan khususnya untuk memproduksi logam-logam berharga dari mineral berkadar rendah dan bersifat kompleks, dengan biaya lebih ekonomis, kebutuhan energi lebih rendah dan lebih sedikit menimbulkan pencemaran lingkungan, bahkan ada yang benar-benar merupakan proses tanpa polusi (Acevedo, 2002; Ghosh, 2011; Johnson, 2013; Taylor, 2013; Pollmann $d k k ., 2016)$.

Bioteknologi adalah cabang ilmu yang mempelajari pendayagunaan mikroorganisme (bakteri, fungi, virus, dan lain-lain) maupun produk dari mikroorganisme (enzim, asam organik, alkohol) dalam proses produksi untuk menghasilkan produk tertentu. Penggunaan mikroorganisme dalam pemrosesan mineral untuk mengekstraksi dan mengambil logamlogam berharga dari mineral primer, konsentrat maupun ampas yang dikenal sebagai bioleaching dan biooksidasi, telah mengantarkannya menuju cabang ilmu baru, yaitu bioteknologi mineral. Dalam tulisan ini, dibahas beberapa landasan teori dasar penggunaan mikroorganisme dalam pemrosesan mineral, aplikasi komersialnya yang telah ada di beberapa negara di dunia, tantangan dan kendalanya serta potensi aplikasinya untuk diterapkan dalam pemrosesan mineral skala industri di Indonesia.

\section{METODE}

Kajian ini menggunakan data yang bersumber dari hasil-hasil penelitian yang telah dilakukan di Indonesia, terutama di Puslitbang Teknologi Mineral dan Batubara, Institut Teknologi Bandung dan Universitas Patimura sepanjang kurun waktu sejak 1996 hingga saat ini. Data lainnya diperoleh dari berbagai instansi terkait seperti Pusat Sumberdaya Geologi, Badan Geologi, Direktorat Jenderal Mineral dan Batubara, Kementerian Perindustrian, Kementerian Perdagangan, serta sumber lain dari literatur dan jurnal ilmiah.

\section{Teknologi Bioleaching dan Biooksidasi}

Sejak awal abad ke-20, beberapa pertambangan batubara di Pennsylvania telah melepaskan efffluent-nya ke sungai Ohio. Effluent tersebut bersifat sangat asam yang setara dengan total laju alir jutaan ton asam sulfat per tahun. Sekitar 1940-an, polusi di Sungai Ohio sudah sangat berat. Asam sulfat yang ada, berasal dari oksidasi sulfida yang berasosiasi dengan batubara. Laju oksidasi ini jauh lebih tinggi daripada tingkat oksidasi secara kimia. Makin jelas kemudian bahwa peningkatan laju reaksi oksidasi disebabkan oleh beberapa katalis yang aktif bekerja di tambang dan di dalam effluent. Katalis ini akhirnya dapat diidentifikasi sebagai komponen mikroorganisme yang hidup di tambang dan ditemukan pula di dalam air asam tambang. Mikroorganisme itu adalah Thiobacillus thiooxidans. Kemudian tahun 1950, Colmer dan Temple berhasil mengisolasi bakteri Chemolithoautotroph dari air asam 
tambang batubara dekat Pittsburg. Bakteri ini mengoksidasi ion fero menjadi feri, dan bakteri ini diberi nama Thiobacillus ferrooxidans. Kemampuan Thiobacillus ferrooxidans dalam mengoksidasi sulfur kemudian dimanfaatkan dalam proses oksidasi dan pelarutan logam sulfida lain seperti kalkopirit (CuFeS2), kalkosit $\left(\mathrm{Cu}_{2} \mathrm{~S}\right)$, kovelit (CuS). Sejak itu, Thiobacillus ferrooxidans diisolasi dari banyak air asam tambang dan penemuan bakteri ini telah menandai era baru dalam memahami fenomena yang berhubungan dengan pembentukan dan degradasi bijih mineral, serta menjadi dasar dari lahirnya teknologi bioleaching dan biooksidasi (Ehrlich, 2004).

Istilah bioleaching dan biooksidasi mempunyai pengertian yang berbeda. Bioleaching adalah pelarutan logam dari mineral menggunakan jasa mikroba untuk memperoleh logam-logam berharga seperti tembaga, nikel, seng, uranium dan kobal. Logam-logam tersebut menjadi larut selama proses berlangsung. Larutannya kemudian diolah lagi untuk memperoleh logam berharganya secara maksimum melalui proses ekstraksi dan penapisan elektrik. Biooksidasi adalah oksidasi mineral oleh bakteri tetapi logam berharganya tidak larut dan tetap berada dalam residu padatan dalam bentuk yang lebih terkonsentrasi. Larutannya sendiri dibuang. Teknologi biooksidasi telah digunakan oleh industri pemrosesan emas sebagai proses pra olahan untuk membuang pirit dan arsenopirit dari bijih emas refraktori (Schippers $d k k ., 2013$ ).

\section{Mekanisme Reaksi Bioleaching dan Biooksidasi}

Mekanisme oksidasi mineral yang dikatalisis oleh bakteri dan jamur telah didiskusikan dan dievaluasi secara luas, di antaranya oleh Taylor (2013), Ghosh (2011), Rawlings dan Johnson (2007). Reaksi pelarutan logam dalam proses biooksidasi mineral sulfida, dapat dituliskan sebagai berikut:

$\mathrm{MS}+2 \mathrm{O}_{2} \rightarrow \mathrm{MSO}_{4}$

M adalah logam bervalensi dua. Reaksi tambahan berikut ini akan terjadi bila ion feri ada dalam lingkungan :

$\mathrm{MS}+2 \mathrm{Fe}^{3+} \rightarrow \mathrm{M}^{2+}+\mathrm{S}^{0}+2 \mathrm{Fe}^{2+}$
Mikroorganisme mempunyai peran dalam meningkatkan regenerasi ion feri dalam larutan dengan cara mengoksidasi ion fero sebagai berikut:

$2 \mathrm{Fe}^{2+}+1 / 2 \mathrm{O}_{2}+2 \mathrm{H}^{+} \rightarrow 2 \mathrm{Fe}^{3+}+\mathrm{H}_{2} \mathrm{O}$

Teknologi biooksidasi mampu membebaskan emas yang terinklusi dalam mineral sulfida sebagai bijih emas refraktori, sehingga memungkinkan untuk memperoleh emas tersebut melalui proses sianidasi konvensional. Biooksidasi arsenopirit dapat dituliskan dalam persamaan reaksi sebagai berikut :

$$
\begin{aligned}
2 \mathrm{FeAsS}+7 \mathrm{O}_{2}+2 \mathrm{H}_{2} \mathrm{O}+4 \mathrm{H}^{+} \rightarrow \\
2 \mathrm{Fe}^{3+}+2 \mathrm{H}_{3} \mathrm{AsO}_{4}+2 \mathrm{HSO}_{4}
\end{aligned}
$$

dan oksidasi pirit adalah sebagai berikut:

$$
\begin{gathered}
2 \mathrm{~S}+3 \mathrm{O}_{2}+2 \mathrm{H}_{2} \mathrm{O} \rightarrow 2 \mathrm{H}_{2} \mathrm{SO}_{4} \\
4 \mathrm{FeS}_{2}+15 \mathrm{O}_{2}+2 \mathrm{H}_{2} \mathrm{O}+4 \mathrm{H}^{+} \rightarrow \\
4 \mathrm{Fe}^{3+}+8 \mathrm{HSO}_{4}^{-}
\end{gathered}
$$

Adapun reaksi bioleaching tembaga mengikuti persamaan reaksi berikut :

$$
\begin{aligned}
& 2 \mathrm{FeS}_{2}+7 \mathrm{O}_{2}+2 \mathrm{H}_{2} \mathrm{O} \rightarrow 2 \mathrm{FeSO}_{4}+2 \mathrm{H}_{2} \mathrm{SO}_{4} \\
& 2 \mathrm{CuFeS}_{2}+81 / 2 \mathrm{O}_{2}+\mathrm{H}_{2} \mathrm{SO}_{4} \rightarrow \\
& 2 \mathrm{CuSO}_{4}+\mathrm{Fe}_{2}\left(\mathrm{SO}_{4}\right)_{3}+\mathrm{H}_{2} \mathrm{O} \\
& \mathrm{Cu}_{2} \mathrm{~S}+2 \mathrm{Fe}^{3+} \rightarrow \mathrm{Cu}^{2+}+2 \mathrm{Fe}^{2+}+\mathrm{CuS} \\
& \mathrm{CuS}+2 \mathrm{Fe}^{3+} \rightarrow 2 \mathrm{Fe}^{2+}+\mathrm{SO} \\
& \mathrm{SO}+3 \mathrm{O}_{2}+2 \mathrm{H}_{2} \mathrm{O} \rightarrow 2 \mathrm{H}_{2} \mathrm{SO}_{4}
\end{aligned}
$$

Reaksi bioleaching nikel (Bohidar, Mohapatra dan Sukla, 2009) :

$\mathrm{NiO}+2 \mathrm{H}^{+} \rightarrow \mathrm{Ni}^{2+}+\mathrm{H}_{2} \mathrm{O}$

Kompleksasi $\mathrm{Ni}$ dengan asam sitrat yang diproduksi fungi sebagai pelaku bioleaching :

$\mathrm{Ni}^{2+}+\mathrm{H}_{3}$ (asam sitrat) $\rightarrow \mathrm{Ni}$ (sitrat) $+3 \mathrm{H}^{+}$

Pengendapan oleh asam oksalat yang diproduksi fungi :

$$
\begin{aligned}
\mathrm{Ni}^{2+}+ & \mathrm{HO}_{2} \mathrm{C} \cdot \mathrm{CO}_{2} \mathrm{H} \rightarrow \\
& \mathrm{Ni}\left(\mathrm{O}_{2} \mathrm{C} \cdot \mathrm{CO}_{2}\right)(\mathrm{S})+2 \mathrm{H}^{+}
\end{aligned}
$$


Pemurnian pasir silika dengan proses bioleaching, kandungan besi dilarutkan oleh asam oksalat yang diproduksi fungi (Lee $d k k$., 2007; Salmimies dkk., 2012):

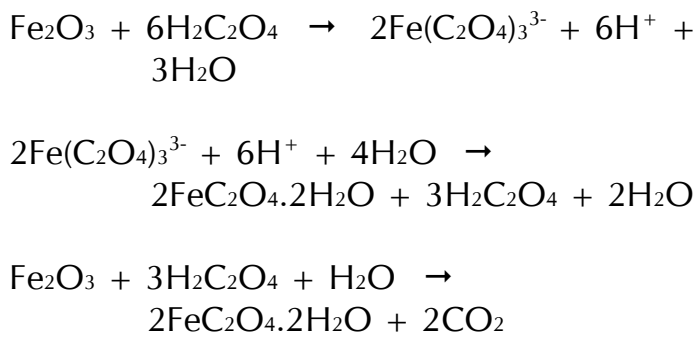

Reaksi bioleaching uranium dapat dituliskan dengan persamaan reaksi berikut:

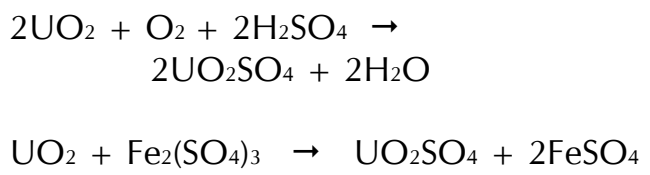

\section{Aplikasi Teknologi Bioleaching dan Biooksidasi secara Komersial}

Mekanisme reaksi secara kimia dan biokimia proses bioleaching dan biooksidasi bijih sulfida telah diteliti dan dikembangkan secara intensif dan ekstensif. Teknologi ini telah diterapkan oleh industri secara komersial untuk bijih emas, tembaga, nikel, uranium dan logam jarang. Biooksidasi emas dalam bijih pirit/arsenopirit di antaranya telah dilakukan di Fairview Mine di Afrika Selatan, Sao Bento Mine di Brazil dan di Ashton Mining Harbour Lights Mine di Australia. Proses biooksidasi bijih refraktori emas terbesar adalah di Kokpatas, Uzbekistan yang mengolah 2.139 ton bijih per hari. Adapun bioleaching tembaga secara komersial telah dilakukan di Chile (Gentina dan Acevedo, 2016), uranium di Spanyol (Williamson $d k k$., 2010; Hamidian, 2011), logam jarang di Finlandia, Mesir (Langwaldt, 2007; Ibrahim dan El-Sheikh, 2011).

Teknologi biooksidasi sejauh ini paling luas diterapkan untuk bijih refraktori emas dengan lebih dari 20 pabrik biooksidasi komersial sebagai pra pengolahan konsentrat emas refraktori sulfidis, yang datanya lebih lengkap seperti disajikan pada Tabel 1 (Brierley, 2010; van Niekerk, van den Heuvel dan van Buuren, 2014). Pabrik-pabrik itu menggunakan tangki aerasi berpengaduk untuk oksidasi mineral pirit dan arsenopirit yang mengunci emas di dalam mineral tersebut. Pabrik Youanmi menggunakan teknologi BacTech Australia yang memanfaatkan kultur bakteri termofilik moderat, Sulfobacillus thermosulfidooxidans, dengan proses biooksidasi terjadi pada suhu 45$55^{\circ} \mathrm{C}$. Adapun pabrik lainnya menggunakan proses BIOX yang memanfaatkan kultur campuran Thiobacillus dan Leptospirillum pada suhu $40-45^{\circ} \mathrm{C}$. Pabrik biooksidasi di tambang Beaconsfield menggunakan kombinasi teknologi BacTech dan Mintek beroperasi di Tasmania. Biooksidasi sebagai pra pengolahan dalam tangki reaktor beroperasi secara komersial hanya untuk konsentrat flotasi bernilai tinggi. Adapun biooksidasi untuk pra pengolahan bernilai rendah dilakukan pada heapleaching seperti yang telah dilakukan China dan di Newmont Gold. Bijih digerus sampai berukuran 12,7 mm. Timbunan mempunyai ventilasi udara dan pra olahan ini berlangsung selama 100 hingga 270 hari. Bijih yang telah teroksidasi kemudian dipindahkan, dinetralisasi dan dilindi. Perolehan emas berkisar antara $60-80 \%$ tergantung sifat mineralogi bijih. Biooksidasi sebagai pra olahan secara heapleaching ini diterapkan bila bijih berkadar emas rendah, biayanya tidak ekonomis bila dibuat konsentrat, mineraloginya bersifat refraktori sulfidis yang tidak bisa dibuat konsentrat atau proyeknya terlalu kecil untuk dapat mendukung proses dengan modal yang besar.

Aplikasi bioteknologi lainnya yang telah meraih sukses dalam pemrosesan mineral adalah bioleaching tembaga. Pengembangan bioleaching tembaga secara komersial tidak bisa dipisahkan dengan sejarah bioleaching tembaga di Chili yang merupakan negara penghasil tembaga terbesar di dunia selama beberapa dekade. Cadangan tembaganya paling besar di bumi ini, namun setelah dieksploitasi sekian lama dan mudahnya mengekstraksi tembaga oksida, mineral dengan kadar tembaga tinggi mulai menipis. Untuk menjaga tingkat produksi tembaga tetap tinggi, perlu introduksi teknologi baru, dan untuk itu, bioleaching telah sukses diaplikasikan. Chili merupakan negara pertama di dunia yang mempunyai operasi bioleaching tembaga sulfida secara komersial. Kini operasi bioleaching telah menyumbang minimal $10 \%$ produksi tembaga Chili (Gentina dan Acevedo, 2016). 
Tabel 1. Pabrik biooksidasi komersial mengolah konsentrat flotasi (Brierley, 2010; van Niekerk, van den Heuvel dan van Buuren, 2014)

\begin{tabular}{lcccc}
\hline \multicolumn{1}{c}{ Lokasi Pabrik } & $\begin{array}{c}\text { Kapasitas } \\
(\mathrm{t} / \text { hari })\end{array}$ & $\begin{array}{c}\text { Kadar S } \\
(\%)\end{array}$ & $\begin{array}{c}\text { Ukuran } \\
\text { reaktor }\left(\mathrm{m}^{3}\right)\end{array}$ & Tahun beroperasi \\
\hline Fairview, Afrika Selatan & 62 & 14,3 & 340 & 1986,1991 - sekarang \\
Sao Bento, Brasil & 150 & 19 & 550 & $1990-$ sekarang \\
Harbour Lights, Australia & 40 & 18 & 160 & $1992-1994$ \\
Wiluna, Australia & 158 & 24 & 480 & $1993-$ sekarang \\
Youanmi, Australia & 120 & & & $1994-1998$ \\
Ashanti, Ghana & 960 & 9,1 & 900 & 1994- sekarang \\
Obuasi, Ghana & 960 & & & 1994-sekarang \\
Beaconsfield, Australia & 1050 & & 262 & 1994-sekarang \\
Coricancha, Peru & 60 & 30 & & 1998-sekarang \\
Tamboraque, Peru & 60 & & 370 & 2000-sekarang \\
Jinfeng, Cina & 70 & & 900 & 2001-sekarang \\
Laizhou, Cina & 100 & & 650 & 2005-sekarang \\
Fosterville, Australia & 211 & 21 & & 2005-sekarang \\
Suzdal, Kazakhstan & 520 & 12 & 66 & 2005-sekarang \\
Bogoso 1, Ghana & 196 & & 895 & 2006-sekarang \\
Bogoso 2, Ghana & 20 & 30 & 1500 & 2007-sekarang \\
Yantai, Cina & 60 & & 1000 & 2007-sekarang \\
Jinfeng, Cina & 820 & 16 & & 2008-sekarang \\
Kokpatas, Uzbekistan & 790 & 9,4 & 900 & 2009-sekarang \\
Sansu, Ghana & 1069 & & & 2010-sekarang \\
Agnes, Afrika Selatan & 2139 & 20 & &
\end{tabular}

Produksi tembaga di Chili umumnya berasal dari eksploitasi bijih tembaga sulfida, terutama yang paling penting berasal dari kalkopirit $\left(\mathrm{CuFeS}_{2}\right)$, kalkosit $\left(\mathrm{Cu}_{2} \mathrm{~S}\right)$, kovelit (CuS), bornit $\left(\mathrm{Cu}_{3} \mathrm{FeS}_{3}\right)$, enargit $\left(\mathrm{Cu}_{3} \mathrm{AsS}_{4}\right)$ dan tenantit $\left(\mathrm{Cu}_{3} \mathrm{AsS}_{3}\right)$ (Gentina dan Acevedo, 2016). Setelah bertahun-tahun dieksploitasi, komposisi mineralogi bijih menjadi berubah. Sebelumnya, mineral tembaga oksida melimpah dan mudah diproduksi dengan kandungan tembaga lebih dari $5 \%$. Namun kini mineral tembaga oksida menjadi makin langka dan yang tertinggal adalah tembaga sulfida dengan kandungan logam $\mathrm{Cu}<1 \%$. Cadangan tembaga di Chili kini didominasi oleh kalkopirit yang mengandung 190 juta ton logam $\mathrm{Cu}$ yang merupakan $30 \%$ cadangan tembaga dunia. Perusahaan Chili pertama yang menggunakan teknologi bioleaching dalam mengolah bijih tembaga sekunder adalah Sociedad Minera Pudahuel yang mulai beroperasi pada 1982. Di Chili kini terdapat 30 perusahaan menggunakan kombinasi teknologi pelindian solvent extractionelectrowinning (SX/EW) dan 13 perusahaan menggunakan bioleaching yang telah menyumbang $10-20 \%$ produksi tembaga Chili.
Bioleaching tembaga skala besar di Chili dilakukan secara bioheapleaching seperti ditunjukkan pada Gambar 1. Mineral tembaga digerus hingga ukuran partikel $1 \mathrm{~cm}$ dalam 2 hingga 3 tahap penggerusan, ditambahkan asam sulfat kemudian diaglomerisasi. Asam sulfat ditambahkan ke atas gundukan melalui irigasi atau penyiraman. Penyiraman diulangi beberapa kali sesuai kebutuhan untuk mengekstraksi tembaga dan mengonsentrasikannya. Aliran gas diinjeksikan dari dasar gundukan untuk menyuplai oksigen dan karbondioksida. Larutan kaya memasuki unit ekstraksi solven yang memurnikan dan mengonsentrasi larutan. Tembaga diperoleh melalui elektrowining. Proses bioleaching ini berlangsung 2 bulan atau lebih.

Dalam proses bioleaching ini, mikroorganisme merupakan pelaku utama. Bioheapleaching tidak berjalan dalam kondisi aseptik sehingga populasi campuran mikroorganisme alami yang terdapat di tambang bertanggung jawab terhadap kelangsungan proses. Biasanya mikroorganisme dengan diversitas yang cukup besar ikut berperan, terutama dari golongan bakteri dan archaea. Tiga bakteri yang telah diidentifikasi secara luas adalah Acidithiobacillus ferroxidans, A. thiooxidans 
dan Leptospirillium ferrooxidans. Agar mikroorganisme itu tumbuh dan dapat melakukan proses pelindian, mikroba tersebut memerlukan nutrisi yang bisa diperoleh dari lingkungannya, yaitu dari bijihnya sendiri. Untuk kondisi tertentu, kadang diperlukan tambahan nitrogen dan fosfor yang bisa diinjeksikan kepada larutan pelindian. Mikroorganisme juga membutuhkan dua komponen gas, yaitu oksigen sebagai akseptor elektron, dan karbondioksida sebagai sumber karbon. Keberadaan kedua gas tersebut tergantung kepada karakteristik perpindahan massa dari sistem bioleaching yang ada.

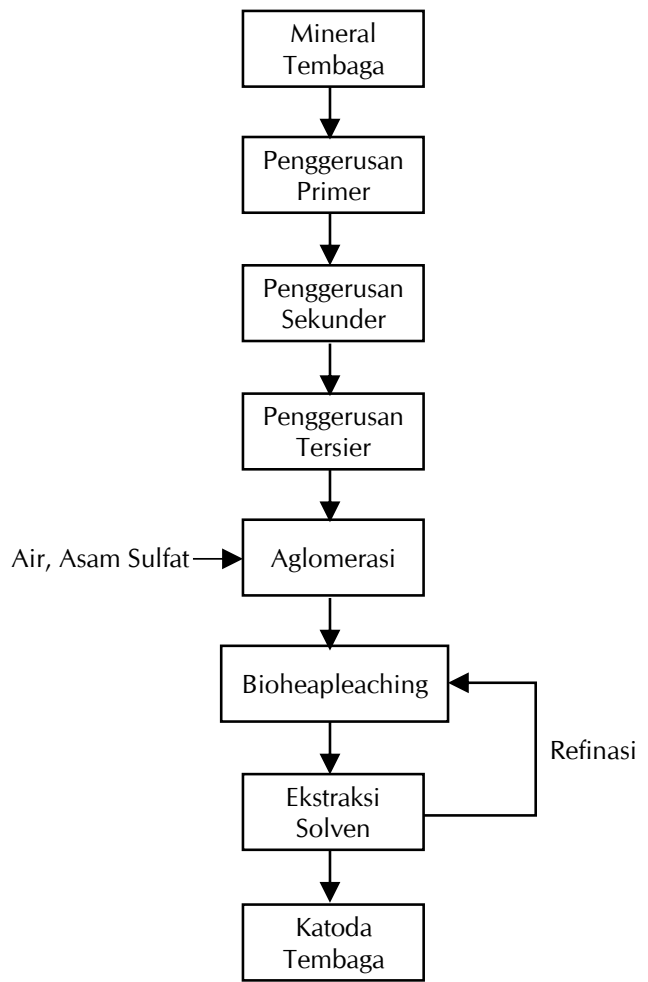

Gambar 1. Diagram alir proses bioheap-leaching tembaga di Chili (Gentina dan Acevedo, 2016)

Sejarah perkembangan bioleaching tembaga di Chili sangat menarik dan memberi pelajaran berharga bagi negara lain yang ingin menerapkan teknologi ini. Kajian bioleaching dimulai pada 1970-an ketika dirintis penelitian terhadap bakteri Acidithiobacillus ferrooxidans oleh Manuel Rodrigues di Fakultas Biologi Universitas Pontificia dan Claudio Gonzales di Fakultas Kimia dan Farmasi, Universitas Chili. Pemerintah Chili kemudian mendirikan 2 institut riset: Mining and Metallurgical Research Centre dan Technological Research Institute. Kedua lembaga penelitian itu mempunyai proyek penelitian bioleaching bijih tembaga dan menerima dukungan ilmiah dan ekonomi dari berbagai proyek internasional di bidang teknologi bioleaching seperti Metallurgical Technology-Copper dari Organization of American States (OAS) 1979-1981, Biotechnology Applied to Copper Mining, OAS 1985-1988. Aktivitas penelitiannya terfokus pada pertumbuhan dan kinetika oksidasi $A$. ferroxidans dalam media tertentu, pemodelan bioleaching tembaga sulfida dan bijih tembaga kadar rendah, ampas serta konsentrat, proses bioleaching dalam kolom dan reaktor berpengaduk, adaptasi mikroorganisme pelaku pelindian dalam persen padatan tinggi. Karena kompleksitas masalah yang dihadapi sangat banyak, maka masalah-masalah proyek penelitian tersebut harus diselesaikan dengan pendekatan multi disiplin ilmu dan multi lembaga, sehingga perlu untuk melibatkan para peneliti dari berbagai universitas, lembaga penelitian dan sektor industri pertambangan. Proyek tersebut mendapat dukungan dana dari United Nation Development Program (UNDP) 1985-1988 sampai meraih keberhasilan sehingga Chili akhirnya kini dikenal sebagai negara terkemuka dalam penelitian bioleaching tembaga di dunia. Beberapa penelitinya kemudian beralih bekerja di perusahaan tambang, khususnya Sociedad Minera Pudahuel (SMP) dan secara efektif dapat memberikan kontribusi pengetahuan dan pengalaman yang didapat sebelumnya dari proyek-proyek penelitian bioleaching.

SMP mendirikan pabrik pengolahan mineral tembaga pertama di dunia menggunakan teknologi bioleaching di tambang Aguirre yang merupakan tambang kecil berkapasitas 14.000 ton per tahun. Sejak 1990 dan seterusnya, SMP mendirikan pabrik-pabrik dengan kapasitas lebih besar : tambang Lince-Michilla kapasitas 22.000 ton per tahun, tambang Quebrada Blanca, Cerro Colorado, Coldelco,s El Teniente, Andacollo, Ivan-Zar, Los Bronces dan tambang La Escondida yang merupakan tambang terbesar. Sukses itu diraih berkat kerjasama yang bersifat sinergis antara ilmuwan dan teknokrat dari akademisi dan industri pertambangan dalam mengembangkan industri bioleaching tembaga. 
Chili merupakan negara utama yang berhasil dengan aplikasi bioleaching tembaga, kemudian diikuti oleh Cina yang juga sangat membutuhkan berbagai logam dalam jumlah besar. Hingga saat ini, di Cina terdapat 21 tambang tembaga dengan pemanfaatan bioleaching untuk pemrosesan mineralnya secara komersial di antaranya tambang Dexing, Yangla, Zijinshan, Guanfang, Zhongtiaoshan, Yulong, Asele, Yongping, Dongchuan, Jinchuan, Dongxiang (Yin dkk., 2018). Wilayah tambang tembaga di Dexing, Asele, Yulong dan Zijinshan, kemudian meluas ke tambang Jiangxi, Tongling dan Daye merupakan tempat untuk riset dan pengembangan (R\&D) yang diterapkan terhadap mineral tembaga kalkosit dan kalkopirit. Tambang Zijinshan mempunyai cadangan bijih kalkosit terbesar di Cina, yaitu sebesar 13,9 juta ton dengan mineral tembaga sulfida kadar rendah (Cu 0,38\%) yang cocok untuk aplikasi teknologi bioleaching. Pabrik ini mulai beroperasi penuh pada 2005 dengan kapasitas produksi 20.000 ton per tahun dan persen ekstraksi tembaga sebesar $80 \%$.

\section{Potensi Aplikasi Teknologi Biooksidasi dan Bioleaching di Indonesia}

Teknologi bioleaching dan biooksidasi telah berkembang cukup pesat dalam 30 tahun terakhir, dan makin banyak industri pengolahan mineral di seluruh dunia yang mengaplikasikan teknologi ini secara komersial. Walaupun demikian, teknologi ini tergolong relatif baru di Indonesia.

Potensi teknologi bioleaching dan biooksidasi untuk mengolah bijih emas refraktori cukup menjanjikan, karena komoditas emas memberi kontribusi devisa yang cukup besar bagi Indonesia. Sumber cadangan bijih emas refraktori yang terinklusi dalam pirit, arsenopirit, pirohit dan kalkopirit seperti yang terdapat di Pongkor, Kalimantan Timur dan Sulawesi Selatan, bahkan di Cikondang, Jawa Barat sekitar $80 \%$ cadangan emas yang ada bersifat refraktori (Fillis, 1988). Tetapi, sampai saat ini, bijih refraktori emas tersebut belum diolah, walaupun kajian-kajian tentang biooksidasi percontoh bijih emas refraktori dari Pongkor Jawa Barat dan Kelian, Kalimantan Timur telah dilakukan oleh Barrett $d k k$. (1993), dan Handayani (1996, 2012, 2014).
Penerapan teknologi hanya dengan sianidasi langsung telah diketahui memberikan hasil sangat rendah, berkisar $18-48 \%$. Bila diberi perlakuan pra olahan dengan teknologi biooksidasi, maka perolehan emas meningkat tajam menjadi 96-98\%. Data tersebut memberi masukan yang sangat berharga bagi industri pemrosesan mineral untuk mengadopsi teknologi biooksidasi secara komersial di Indonesia. Proses ini bisa sangat kompetitif untuk mengolah bijih emas refraktori karena harga emas yang tinggi saat ini.

Metode biooksidasi yang yang paling sesuai diterapkan untuk jenis bijih mineral refraktori emas Indonesia adalah agitated tank leaching atau bioheapleaching (Handayani, 2014). Pemilihan metode tersebut juga harus didasarkan kepada pertimbangan aspek ilmiah dan ekonomi, seperti karakteristik kimia mineral, kadar dan nilai emas yang terkandung serta beberapa faktor lokal kemudian menguji karakteristik bijih atau konsentrat terhadap proses biooksidasi. Berdasarkan pertimbangan aspek teknologi dan ekonomis, maka diperlukan studi kelayakan yang akurat dan menyeluruh.

\section{PENELITIAN BIOLEACHING DAN BIOOKSIDASI YANG TELAH DILAKUKAN DI INDONESIA}

Penelitian bioteknologi mineral yang telah dilakukan di Indonesia antara lain:

1. Biooksidasi emas (Handayani, 1996, 2012, 2014),

2. Bioleaching nikel (Astuti, Mubarok dan Chaerun, 2011; Handayani dan Suratman, 2016; Mubarok, Pratama dan Chaerun, 2016; Kurniawan et al., 2018),

3. Bioleaching tembaga (Chaerun $d k k ., 2017$, 2018; Male dkk., 2019),

4. Bioleaching fosfat (Handayani dan Suratman, 2009, 2015; Handayani, Wahyudi dan Suratman, 2009; Handayani, 2011),

5. Bioleaching pasir silika (Suratman dan Handayani, 2014),

6. Bioleaching mangan (Retnaningrum dan Wilopo, 2019).

Resume penelitian-penelitian tersebut adalah sebagai berikut. 


\section{Biooksidasi Bijih Emas Refraktori}

Pengolahan bijih emas refraktori dengan metode kimiawi yaitu sianidasi secara langsung telah memberikan persen ekstraksi emas yang rendah karena emas pada bijih ini terinklusi dalam mineral-mineral sulfida sehingga menghambat kontak dengan sianida.

Metode biooksidasi menggunakan mikroorganisme telah dilakukan dengan bakteri dari spesies Thiobacillus ferrooxidans untuk pra olahan bijih emas refraktori asal Kalimantan Timur dalam melarutkan mineral sulfida dari ikatan emas. Efektivitas proses pelindian selama 42 hari oleh bakteri tersebut menunjukkan adanya perolehan emas sebesar $87,1 \%$ dibandingkan metode sianidasi langsung tanpa pra olahan yang dicapai sebesar 38,7\%. Pemanfaatan kultur bakteri konsorsium Acidithiobacillus ferrooxsidans dan $A$. thiooxidans dapat meningkatkan perolehan emas menjadi $98 \%$ dengan waktu proses yang lebih singkat selama 28 hari (Handayani, 1996).

\section{Bioleaching Nikel dari Bijih Nikel Kadar Rendah (Limonit)}

Dalam penelitian yang dilakukan di Puslitbang Tekmira (Handayani dan Suratman, 2016), pelindian nikel oleh jamur indigenus yang diisolasi dari bijih limonit dan galur (strain) jamur yang dikarakterisasi dan diidentifikasi sebagai Aspergillus sp dan Penicillium sp. dipelajari untuk mengembangkan teknik ekstraksi nikel dari bijih nikel kadar rendah. Analisis XRD menunjukkan komposisi mineral utama percontoh bijih terdiri dari goetit dan mineral silika. Percobaan pelindian dilakukan secara aseptik dalam $250 \mathrm{ml}$ labu erlenmeyer pada suhu kamar dan agitasi $150 \mathrm{rpm}$. Aspergillus sp melindi nikel lebih baik dan lebih efisien dibandingkan Penicillium $s p$. Maksimum ekstraksi nikel sebesar 57\% diperoleh pada pelindian secara langsung oleh Aspergillus sp menggunakan 5\% solid selama 20 hari.

Penelitian ekstraksi nikel dari bijih laterit nikel Pomalaa, Sulawesi tenggara juga telah dilakukan di Institut Teknologi Bandung (Astuti, Mubarok dan Chaerun, 2011). Proses bioleaching dilakukan oleh konsorsium jamur Penicillium veruculosum dan Galactomyces geotrichum sebagai produsen asam, menggunakan media limbah produksi makanan tahu, tempe dan molases. Konsorsium jamur tersebut dapat memproduksi asam sitrat, asam laktat dan asam asetat sebagai agen pelindian. Proses bioleaching dapat mengekstraksi $24,5 \%$ nikel setelah waktu satu minggu.

Sementara itu, pada penelitian bioleaching nikel lainnya yang dilakukan terhadap bijih limonit dari Pulau Gag oleh konsorsium mikroba Alicyclobacillus ferrooxidans, Bacillus mucilaginosus dan Pseudomonas putida (Mubarok, Pratama dan Chaerun, 2016), diperoleh persen ekstraksi nikel tertinggi sebesar $34,3 \%$ setelah proses berlangsung selama 28 hari.

Pelindian nikel berkaitan erat dengan penurunan $\mathrm{pH}$ dan produksi asam organik oleh pertumbuhan fungi dalam medium glukosa sebagai sumber karbon, namun pelindian dalam persentasi solid yang lebih tinggi menurunkan ekstraksi nikel. Hasil-hasil tersebut menunjukkan bahwa optimasi proses masih perlu dilakukan untuk menjaga nilai $\mathrm{pH}$ yang dibutuhkan agar dapat diperoleh persen ekstraksi nikel yang lebih tinggi.

\section{Bioleaching Tembaga}

Penelitian isolasi bakteri untuk proses bioleaching tembaga telah dilakukan di Universitas Patimura (Male $d k k ., 2019$ ). Bakteri tersebut diisolasi dari air asam tambang di sekitar area tambang tembaga di Pulau Wetar, Maluku. Digunakan medium isolasi Leathen yang dioptimasi dengan trypton soya broth (TSB) hingga diperoleh isolat Acidithiobacillus sp. Chaerun dkk. (2017) melakukan penelitian bioleaching tembaga dari bijih tembaga porfiri yang berasal dari sungai Mak Gorontalo menggunakan bakteri pengoksidasi besi dan belerang. Bijih tembaga tersebut mengandung kalkosit $\left(\mathrm{Cu}_{2} \mathrm{~S}\right)$, kovelit $(\mathrm{CuS})$, dan mineral oksida seperti kuprit $\left(\mathrm{Cu}_{2} \mathrm{O}\right)$ dan tenorit $(\mathrm{CuO})$. Ekstraksi bijih tembaga kompleks itu biasanya memerlukan temperatur dan tekanan tinggi, dan/atau konsentrasi asam tinggi. Teknologi bioleaching bisa menjadi alternatif proses yang lebih ekonomis karena proses bisa berlangsung pada temperatur kamar namun memang memerlukan waktu proses yang lebih lama, bisa hingga 14 hari. Penelitian ini merupakan 
langkah awal yang bisa sangat bermanfaat dalam mengembangkan proses ekstraksi bijih tembaga kompleks yang lebih ekonomis dan ramah lingkungan di Indonesia (Chaerun $d k k$., 2017).

\section{Bioleaching Batuan Fosfat untuk Produksi Pupuk Fosfat}

Jamur yang mempunyai potensi melarutkan mineral fosfat telah berhasil diisolasi dari permukaan batuan fosfat asal Cijulang dan diidentifikasi sebagai Penicillium sp (Handayani, Wahyudi dan Suratman, 2009). Kemampuan jamur dalam melarutkan fosfat telah diuji dan pengaruh beberapa parameter seperti ukuran partikel mineral, konsentrasi bijih dan $\mathrm{pH}$ awal medium diteliti untuk mengkarakterisasi pelarutan fosfat oleh Penicillium sp. Data XRD menunjukkan adanya hidroksil apatit $\mathrm{Ca}_{5}\left(\mathrm{PO}_{4}, \mathrm{CO}_{3}\right)_{3} \mathrm{OH}$ sebagai sumber utama fosfor. Strain jamur Penicillium sp memproduksi asam oksalat dan asam sitrat selama fermentasi glukosa yang mengakibatkan penurunan $\mathrm{pH}$ medium pertumbuhan jamur. Hasil percobaan juga menunjukkan adanya hubungan antara pelarutan fosfat dengan produksi asam organik oleh jamur. Di samping itu, ukuran partikel mineral, konsentrasi bijih dan $\mathrm{pH}$ awal medium mempunyai pengaruh yang signifikan terhadap pelarutan fosfor dari batuan fosfat. Kecepatan pelarutan yang optimal diperoleh pada ukuran partikel -200 mesh dan 5\% konsentrasi bijih. Kisaran $\mathrm{pH}$ awal optimum adalah 6-7 dan pada $\mathrm{pH}$ awal 4 mulai menunjukkan hambatan dalam pelarutan fosfat. Maksimum pelarutan fosfat sebesar 42,8 $\%$ diperoleh pada kondisi menggunakan ukuran partikel -200 mesh, $5 \%$ padatan dan $\mathrm{pH}$ awal 6 setelah proses selama 16 hari.

\section{Bioleaching Pasir Silika untuk Mendapatkan Silika Kemurnian Tinggi}

Nilai komersial bahan baku pasir silika sangat dipengaruhi oleh adanya kandungan besi, aluminium dan logam-logam pengotor lainnya yang dapat mengganggu produk manufaktur. Teknologi pelindian pasir silika Sambiroto telah diteliti dengan metode kimia (menggunakan $\mathrm{HCl}$ dan $\mathrm{H}_{2} \mathrm{SO}_{4}$ ) dan biologi (menggunakan metabolit Aspergillus niger). Laju pelindian secara kimia dan biologi berbeda tergantung kepada agen pelindi yang digunakan dan konsentrasinya. Hasil percobaan menunjukkan proses benefisiasi dapat meningkatkan kualitas percontoh pasir silika hingga mencapai kemurnian tinggi. Pengotor utama dan minor $\mathrm{Fe}, \mathrm{Al}, \mathrm{Ca}, \mathrm{Cr}, \mathrm{Ti}, \mathrm{Zr}$ dan $\mathrm{Cu}$ berkurang secara nyata dengan pelindian $\mathrm{HCl}$ dan $\mathrm{H}_{2} \mathrm{SO}_{4} 4 \mathrm{M}$ yang berlangsung pada suhu $90^{\circ} \mathrm{C}$ dengan $30 \%$ padatan selama 4 jam. Komposisi kimia pasir silika membaik dengan meningkatnya $\mathrm{SiO}_{2}$ dari 97,24 menjadi $98,77 \%$, sedangkan jumlah pengotor menurun dari 1,148 menjadi $0,237 \%$. Perubahan ini menjadikan produk benefisiasi sangat mendekati spesifikasi umpan metallurgical grade silicon untuk material maju. Di antara kedua metode yang diuji, pelindian kimia dengan $\mathrm{HCl}$ dan $\mathrm{H}_{2} \mathrm{SO}_{4}$ paling efisien dalam hal meningkatkan persentasi kandungan $\mathrm{SiO}_{2}$ dan penghilangan logam pengotor dibandingkan pelindian secara biologi. Namun demikian, pelindian biologi mampu memproduksi pasir silika dengan kandungan minimal $\mathrm{Fe}$ dan $\mathrm{Al}$ untuk peruntukan industri gelas kualitas tinggi. Karakteristik dari kedua metode itu telah membuka kemungkinan untuk aplikasinya dalam skala industri.

\section{PROGRAM PENGEMBANGAN}

Untuk mendukung program konservasi dan peningkatan nilai tambah mineral secara berkelanjutan dan mempertimbangkan peran bioteknologi dalam pengolahan mineral, maka perlu dilakukan optimasi penelitian bioleaching dan biooksidasi mineral-mineral berkadar rendah, terutama emas, nikel, silika dan logamlogam jarang, serta meningkatkan skalanya ke pilot plant sehingga teknologi ini dapat berperan pada peningkatan perolehan logam berharga dari bijih marjinal. Hal itu dapat dilakukan melalui kerjasama dengan berbagai universitas dan perusahaan-perusahaan tambang yang memiliki cadangan bijih kadar rendah yang belum diolah ataupun ampas tambang yang masih mengandung logam-logam berharga kadar rendah. Penelitian dan pengembangan teknologi ini di seluruh dunia masih terus berlanjut seperti dalam area modifikasi genetika mikroorganisme pelaku bioleaching serta studi detail biokimianya untuk eksploitasi lebih lanjut dalam skala industri yang lebih besar dan lebih luas. 


\section{KESIMPULAN DAN SARAN}

Berbagai kelemahan teknologi pemrosesan mineral konvensional terhadap bijih kadar rendah dan ampas telah menjadikan penggunaan mikroorganisme dalam industri ini dirasakan makin penting peranannya di masa kini dan masa depan. Mineral berkadar tinggi akhirnya akan makin habis dan tinggal mineral berkadar rendah dan kompleks yang tidak akan ekonomis lagi bila diolah dengan teknologi pemrosesan konvensional yang umum diterapkan saat ini. Teknologi biooksidasi dan bioleaching di Indonesia bisa mulai dijajagi untuk diterapkan dalam pemrosesan bijih emas refraktori, pasir silika dan mineral pembawa logam jarang yang cadangannya cukup besar di Indonesia. Peran bioteknologi pada peningkatan perolehan emas dan pemurnian silika dengan metode bioleaching dan bioksidasi menggunakan kultur mikroba dari masing-masing lokasi mineral telah menunjukkan hasil uji skala laboratorium yang baik. Persen ekstraksi emas meningkat tajam dan pemurnian silika telah berhasil baik, namun demikian masih perlu mendapat kesempatan untuk uji skala pilot sebelum diterapkan di lapangan agar metode ini dapat dimanfaatkan pada skala komersial.

Oleh karena itu, penelitian maupun penerapannya diharapkan mendapat dukungan yang cukup memadai dari pemerintah dan industri pertambangan sebagai sebuah transfer teknologi ke industri untuk mengantisipasi masa depan yang pasti akan kita hadapi. Kini di seluruh dunia sudah ada lebih dari 30 negara yang telah menerapkan teknologi biooksidasi dan bioleaching untuk mengolah bijih emas refraktori, bijih tembaga, nikel dan logam jarang. Indonesia pun hendaknya melakukan hal yang sama agar dapat meningkatkan nilai tambah terhadap produk industri pertambangannya.

\section{UCAPAN TERIMA KASIH}

Penulis menyampaikan terima kasih kepada Puslitbang Teknologi Mineral dan Batubara yang telah memberikan izin untuk mempublikasikan tulisan ini. Ucapan terima kasih disampaikan pula kepada para kolega, khususnya Tatang Wahyudi dan Suratman atas berbagai diskusi yang berharga terhadap materi tulisan.

\section{DAFTAR PUSTAKA}

Acevedo, F. (2002) "Present and future of bioleaching in developing countries," Electronic Journal of Biotechnology, 5(2). doi: 10.2225/vol5-issue2-fulltext-10.

Astuti, W., Mubarok, M. Z. dan Chaerun, S. K. (2011) "Prospek fungal bioleaching untuk pengolahan bijih nikel laterit di Indonesia," in Prosiding Seminar Material dan Metalurgi 2011. Banten: LIPI, hal. 141-150.

Barrett, J., Hughes, M. N., Karavaiko, G. I. dan Spencer, P. A. (1993) Metal extraction by bacterial oxidation of minerals. New York: Ellis Horwood Ltd.

Bobadilla-Fazzini, R. A., Pérez, A., Gautier, V., Jordan, H. dan Parada, P. (2017) "Primary copper sulfides bioleaching vs. chloride leaching: Advantages and drawbacks," Hydrometallurgy, 168, hal. 26-31. doi: 10.1016/j.hydromet.2016.08.008.

Bohidar, S., Mohapatra, S. dan Sukla, L. B. (2009) "Nickel recovery from chromite overburden of Sukinda using fungal strains," International Journal of Integrative Biology, 5(2), hal. 103107.

Borja, D., Nguyen, K., Silva, R., Park, J., Gupta, V., Han, Y., Lee, Y. dan Kim, H. (2016) "Experiences and future challenges of bioleaching research in South Korea," Minerals, 6(4), hal. 128(1-21). doi: 10.3390/min6040128.

Brierley, C. L. (2010) "Management in actionbiomining: Biomining Beckons," Mining Magazine, hal. 201:324-328.

Butu, A., Rodino, S., Dobre, A. dan Butu, M. (2016) "Potential of microbial functional communities for high-tech critical metls recovery," Studia Universitatis "Vasile Goldiş", Seria Ştiinţele Vieţii, 26(2), hal. 287-292.

Chaerun, S. K., Putri, F. Y., Mubarok, M. Z., Minwal, W. P. dan Ichlas, Z. T. (2017) "Bioleaching of supergene porphyry copper ores from sungai Mak Gorontalo of Indonesia by an iron- and sulfur-oxidizing mixotrophic bacterium," Solid State Phenomena, 262, hal. 20-23.

doi: 10.4028/www.scientific.net/SSP.262.20.

Chaerun, S. K., Putri, F. Y., Minwal, W. P., Ichlas, Z. T. dan Mubarok, M. Z. (2018) "Bacterial leaching of an Indonesian complex copper sulfide ore using an iron-oxidizing indigenous 
bacterium," Microbiology Indonesia, 12(1), hal. 1-6. doi: 10.5454/mi.12.1.1.

Ehrlich, H. L. (2004) “Review: Beginnings of rational bioleaching and highlights in the development of biohydrometallurgy: a brief history," The European Journal of Mineral Processing and Environmental Protection, 4(2), hal. 102-112.

Fillis, P. N. (1988) Independent geologist report on Cikondang Project, West Java.

Gentina, J. dan Acevedo, F. (2016) "Copper bioleaching in Chile," Minerals, 6(1), hal. 23. doi: 10.3390/min6010023.

Ghosh, A. (2011) Bioleaching-application of biotechnology in mining industry, www.biotecharticles.com. Tersedia pada: https://www.biotecharticles.com/Applications -Article/Bioleaching-Application-ofBiotechnology-in-Mining-Industry-850.html (Diakses: 15 Desember 2019).

Hamidian, H. (2011) "Microbial Leaching of Uranium Ore," in Tsvetkov, P. (ed.) Nuclear Power - Deployment, Operation and Sustainability. InTech, hal. 291-304. doi: 10.5772/17941.

Handayani, S. (1996) "Biooksidasi bijih emas refraktori Kalimantan Timur dengan Thiobacillus ferrooxidans," in Prosiding Seminar Temu Peneliti Muda Departemen Pertambangan dan Energi: Peran Lembaga Litbang dalam Menunjang Industri Pertambangan di Indonesia.

Handayani, S. (2011) "Effects of temperature and nutrient feed on the production of oxalic acid by Aspergillus niger," Indonesian Mining Journal, 14(3), hal. 108-114.

Handayani, S. (2012) "Pengaruh penambahan ion $\mathrm{Ag} 2+$ terhadap laju biooksidasi mineral sulfida," Jurnal Teknologi Mineral dan Batubara, 8(2), hal. 88-96.

Handayani, S. (2014) Biooksidasi: Teknologi alternatif pengolahan bijih emas refraktori. Puslitbang tekMIRA.

Handayani, S. dan Suratman (2009) "Production of oxalic acid by Aspergillus niger," Indonesian Mining Journal, 12(2), hal. 85-89.

Handayani, S. dan Suratman (2015) "Biosolubilization of phosphate rock by Penicillium sp," Indonesian Mining Journal, 18(1), hal. 29-38.
Handayani, S. dan Suratman, S. (2016) "Bioleaching of low grade nickel ore using indigenous fungi," Indonesian Mining Journal, 19(3), hal. 143-152. doi: 10.30556/imj.Vol19.No3.2016.540.

Handayani, S., Wahyudi, T. dan Suratman (2009) "Studi bioleaching batuan fosfat menggunakan jamur Aspergillus niger," Jurnal Teknologi Mineral dan Batubara, 5(4), hal. 183-190.

Ibrahim, H. A. dan El-Sheikh, E. M. (2011) "Bioleaching treatment of Abu Zeneima uraniferous gibbsite ore material for recovering $\mathrm{U}$, REEs, Al and Zn," Research Journal of Chemical Sciences, 1(4), hal. 55-66.

Johnson, D. B. (2013) “Development and application of biotechnologies in the metal mining industry," Environmental Science and Pollution Research, 20(11), hal. 7768-7776. doi: 10.1007/s11356-013-1482-7.

Kurniawan, R., Juhanda, S., Gustinah, H. M. dan Pratami, A. P. (2018) "Aplikasi bioleaching dalam pemisahan logam nikel oksida dengan jamur Aspergillus niger dan Penicillium chrysogenum," in Prosiding Seminar Nasional Teknik Kimia "Kejuangan." Yogyakarta: UPN "Veteran" Yogyakarta, hal. A2-(1-7).

Langwaldt, J. (2007) "Bioleaching of multimetal black shale by thermophilic micro-organisms," Advanced Materials Research, 20-21, hal. 167-167.

doi: $\quad 10.4028 / w w w . s c i e n t i f i c . n e t / A M R .20-$ 21.167.

Lee, S. O., Tran, T., Jung, B. H., Kim, S. J. dan Kim, M. J. (2007) "Dissolution of iron oxide using oxalic acid," Hydrometallurgy, 87(3-4), hal. 91-99.

doi: 10.1016/j.hydromet.2007.02.005.

Male, Y. T., W.S. Modok, D., A. Seumahu, C. dan Malle, D. (2019) "Isolasi mikroba dari air asam tambang pada area pertambangan tembaga di pulau Wetar, Provinsi Maluku," Indo. J. Chem. Res., 6(2), hal. 101-106. doi: 10.30598//ijcr.2019.6-thi.

Mubarok, M. Z., Pratama, B. E. dan Chaerun, S. K. (2016) "Bioleaching nikel dari bijih limonit Pulau Gag menggunakan bakteri mixotrof," Jurnal Teknologi Mineral dan Batubara, 12(1), hal. 69-79.

doi: 10.30556/jtmb.Vol12.No1.2016.232.

van Niekerk, J., van den Heuvel, C. dan van Buuren, C. (2014) Complete refractory gold solution. 
Pollmann, K., Kutschke, S., Matys, S., Kostudis, S., Hopfe, S. dan Raff, J. (2016) "Novel biotechnological approaches for the recovery of metals from primary and secondary resources," Minerals, 6(2), hal. 54. doi: 10.3390/min6020054.

Rawlings, D. E. dan Johnson, D. B. (2007) "The microbiology of biomining: development and optimization of mineral-oxidizing microbial consortia," Microbiology, 153(2), hal. 315324. doi: 10.1099/mic.0.2006/001206-0.

Retnaningrum, E. dan Wilopo, W. (2019) “Pyrolusite bioleaching by an indigenous acidithiobacillus sp KL3 isolated from an Indonesian sulfurous river sediment," Indonesian Journal of Chemistry, 19(3), hal. 712. doi: 10.22146/ijc.38898.

Salmimies, R., Mannila, M., Kallas, J. dan Häkkinen, A. (2012) "Acidic dissolution of hematite: Kinetic and thermodynamic investigations with oxalic acid," International Journal of Mineral Processing, 110-111, hal. 121-125. doi: 10.1016/j.minpro.2012.04.001.

Schippers, A., Hedrich, S., Vasters, J., Drobe, M., Sand, W. dan Willscher, S. (2013) "Biomining: Metal Recovery from Ores with Microorganisms," in Schippers, A., Glombitza, F., dan Sand, W. (ed.) Geobiotechnology I (Metal-related Issues). Advances i. Berlin
Heidelberg: Springer Berlin Heidelberg, hal. 1-47. doi: 10.1007/10_2013_216.

Suratman dan Handayani, S. (2014) "Beneficiation of Sambiroto silica sand by chemical and biological leachings," Indonesian Mining Journal, 17(3), hal. 134-143. Tersedia pada: http://jurnal.tekmira.esdm.go.id/index.php/imj /article/view/318.

Taylor, A. (2013) "Developments in the processing of refractory and complex gold ores," in AusIMM Bendigo Technical Meeting. Melbourne, Australia: ALTA Metallurgical Services Publications, hal. 1-15.

Williamson, A. L., Payne, R., Kerr, F., Hall, S. dan Spiers, G. A. (2010) "Microbes: Uranium miners, money makers and problem solvers," in Lam, E. K., Rowsoti, J. W., dan Ozberk, E. (ed.) Uranium 2010: Proceedings of the 3rd International Conference on Uranium 40 Annual Hydrometallurgy Meeting. Saskatoon: Met Soc, hal. 531-548.

Yin, S., Wang, L., Kabwe, E., Chen, X., Yan, R., An, K., Zhang, L. dan Wu, A. (2018) "Copper bioleaching in China: Review and prospect," Minerals, 8(2), hal. 32. doi: 10.3390/min8020032. 